KATALIN SZAMEL *

\title{
Legal and Non-Legal Aspects of the Reform Process of the Hungarian Higher Education System
}

\begin{abstract}
The essay surveys Hungarian higher educational reform in a historical perspective. Higher education is a special branch of public administration, where investment to human capital is of corollary importance even if the educational, research and fiscal autonomy of the given institutions is fully respected. The author investigates the legal aspects of how government oversight and supervision (as envisaged in the communist model) has been dismantled over the past 25 years in Hungary. There is no doubt: with the development of institutional autonomy, state subsidies decline and higher educational institutions need to make an increasing effort to simultaneously maintain financial stability, meet market demands and reverse the current trend of deterioration regarding the quality of education. It is for this reason that the negotiations between higher educational institutions and the state must remain within the legal framework so that government supervision will not transform into total neglection. governance.
\end{abstract}

Keywords: Hungarian higher education system, autonomy, institutions of higher education, university, college, credit system, normative financing, student loan, Credit Council

\section{Introduction: Higher Education-a Point of Conflict}

Preparatory work done in the process of drafting new legal regulation within a specific sphere of the law almost always brings up issues beyond the given subject tackled, and brings into focus contradictions that exist within the entirety of the legal system. This is a problem for scholars-who approach the legal regulation of a given sector with a scientific attitude-because the scientist can see beyond the specific task at hand, and when given the chance to draft law will inevitably try to, at the same time, remedy other internal conflict that exists within the legal system. This is particularly true when the task at hand is the regulation of an area known to be a key sector of the economy, and the nature of the reform to be rolled out is such that it promises comprehensive change, which-if successful-has the promise of leading to a paradigm shift.

Senior Research Fellow, Institute for Legal Studies of the Hungarian Academy of Sciences, H-1014, Budapest, Országház u. 30.

E-mail: szamelk@jog.mta.hu 
It is no surprise that in similar situations the process of drafting law becomes closely tied to politics and becomes a point of conflict for politicians. In fact, the clash of interests that occurs in this phase can be quite beneficial to the process as a whole, because it can lead to an outcome that has a reasonable chance of being implemented in the end. It is far less fortunate if the process of legislation is caught in the crossfire of political animosity, and is faced with various interest groups strong enough to hijack the process, in the sense that their activity can lead to the neutralization of the most forward looking elements of the reform.

There is no doubt that the population at large has always been keenly interested-in fact has been looking forward to-the changes affecting higher education, and it could also be seen that those Hungarian intellectuals working as academics employed by public universities have long been successful at slowing the pace of reforms. This attitude is rooted in their understanding that the intellectual capital represented by the concentration of their expertise at the universities makes them the most apt, competent, and committed body fit for the task. This very palpable intellectual advantage led to the birth of a concept of autonomy, which in practice meant the attempt to minimize dependency on the state. This endeavor was more-or-less successful, and also had the added benefit of providing a reasonably effective shield protecting higher education from attempts at change generated from outside-and this was true during even perhaps in the most dictatorial of political times.

State-socialist management of higher education was-despite all its attemptsmerely a never fully implemented experiment at making higher education uniform by way of breaking up and breaking down university autonomy. However, higher education possessed a strong enough lobby position to maintain its relative independence at all times, and even increase the level of its autonomy when the time had become ripe for these measures to be brought. The reason why it is important to bring into the discussion these early steps of the reform of higher education that started in 2002 (and its outcome as well) is that the genesis of the process is essential to understanding the nature of the contradictions the reform encountered after it was launched by the Hungarian Government in 2002.

\section{Education Reform as an Attempt at Breaking the Monopoly of State Control}

Law No. 1985. I. on Education was the first of its kind (enacted still in the time of state-socialism), in the sense that it was in fact reform oriented in practical terms, and not merely as a verbally declared goal.

By the 1970's (during the years of the so-called new economic mechanism, when several sectors were targeted for real change) renewal of education had 
also become necessary. Serious reform concepts were formulated by the staff of various government ministries involved with matters of higher education, but it was only in 1984 that these were complied into a single program of development that could serve as the basis for drafting a comprehensive new law. (Those directives that tried to introduce change prior to 1984 primarily attempted to reform the internal structure of institutions of higher education, but failed because the institutions only formally implemented the changes mandated, or did not do so at all.) The final draft of the law was based on the concepts outlined in the program, and therefore contained a lot of important changes to what was the declared purpose, content, and methodology of education, and the way educational and pedagogic institutions operated. As a novelty, it contained the rights of students of various ages, and dealt with the relations between educational institutions and society-issues that had previously been outside the scope of legal regulation.

In 1985, when all levels of education were regulated in a single law for the first (and in fact also for the last) time, legislators attempted to draw up uniform principals and a common general section for the legal regulation of higher education and lower levels of education as well. This solution did not stand the test of time and proved unsuccessful from a legal perspective. This was due to the fact that both the internal management structures and outside control mechanisms of the two types of schools (lower and higher education) have different characteristics.

General public education traditionally has had a management structure that is not collective in nature (even though the teaching staff also participates, and at times parents' representatives and even students do so as well), rather it is based on a system of personal responsibility of a single director. In contrast, at institutions of higher education-despite having a single person responsible for the proper management of the school-most important decisions are made by committee.

Due to the fact that participation in public education is mandated by law up to a certain age, this branch of education has a relatively tight professional leadership control attached, which prescribes the substance of learning, in other words the material to be taught to students. This is true despite the fact that the degree, nature, and intensity of this leadership can vary a great deal, i.e. state regulation has varying degrees of detail and rigor. In contrast, higher education has traditionally been significantly freer in determining the content of what is being taught, in part because in this framework teaching is also tied to the principal of freedom of research (as a right of the academia). This makes it much easier for research findings to make their way into the textbooks and the substance of the curriculum, therefore larger discrepancies can be tolerated- 
and are in fact desirable-regarding the knowledge acquired and views held by various university students. There are further differences in how these institutions are chartered and financed as well.

Nevertheless, the legal definition of common principles that apply to all levels of education uniformly was politically important, and the new law did in fact cause a significant system-level overhaul to start in the sphere of education. (For example, it lead to more ethnic minority rights being observed, the reinstatement of various faith-based educational institutions, and more forceful attempts at advancing university autonomy.) However, a negative aspect of this single universal law was that certain nondesireable concepts and institutions were fixed by it, and solidified enough to be more difficult to change afterwards.

It had regional political significance that the right was guaranteed by law for ethnic minorities to study using their native language at higher levels of education. There was another significant advance in comparison to the prior state of affairs, because for the first time a law declared the principal of professional independence for educational institutions, which was in stark contrast to state-socialist education policy, which-as stated previously-due to one of its main faults tried to force uniformity onto the system, (primarily in terms of ideology, but in other matters as well).

The law attempted to make the organizational structure of institutions orderly by doing away with certain types of institutions (e.g. post-elementary school training institutions) and also removed the so-called university-like colleges, and so-called upper-level institutions. In the end, only the college and the university remained as the two exclusive (legitimate) forms that an institution of higher education could be chartered in.

Following are the major regulations in connection with central administrative rights granting control over educational matters:

- A "central director" capacity was granted over institutions of higher education for what was defined as a "direct" ministerial capacity, and maintained the concept of a "minister involved in training". (The latter concept is based on the fact that institutions of higher education were structurally under various ministers most closely associated with the given sector, and did not belong to the ministry of education itself.)

- Building on the experience that the minister benefited a great deal in his/her director capacity from the support provided by expert-collectives, the law prescribed the participation of expert-committees with regard to certain activities of the directing ministers.

- Proposal to widen the sphere of 'maintainers' (i.e. institutions chartered by entities other than the state), but gave no further detailed regulation, instead turned the responsibility for the resolution of the issue over to 
the Council of Ministers, with the added remark that-in general-the chartering of a new institution is conditional on the authorization of the Minister of Culture (who was-despite the often changing contemporaneous name-also responsible for education matters).

It was a significant change in the status of institutions of higher education that their professional independence was guaranteed at the level of law. The law took into account this principle and the duties of institutions of higher education when it determined the key areas of independence, which included the right to independently decide the substance of education, to organize scientific research programs, and to manage student matters with a large degree of independence; matters that institutions of higher education were required to manage based on their own fixed rules. According to the letter of the law, it is also a guarantee of independence that institutions of higher education gained the right to voice an opinion in all matters where the decision making power was the competence of the directing minister or other superior administrative body. In addition, institutions of higher education had the general right to make proposals; furthermore, the directing minister had a duty of passing on relevant information to institutions that would be affected by certain planned measures.

Management of institutions of higher education was split between the single person at the head of the institution-who carried overall liability for the general operation of the institution-, and various advisory committees; and in practice was their joint task. There were two different types of bodies that operated within institutions of higher education: representative councils and professional boards. Within the framework of separate legal regulations, institutions of higher education had the right to determine the makeup of both kinds of bodies, set the ratio of elected and appointed (invited) members; as well as the rules according to which these were set up and operated. The purpose of setting up professional bodies was to function as professional forums gathering expertise to support the interests of the institution and its educational activities, to foster productive interaction between theoretical and practical work, to organize and manage scientific research projects within the institutions, and to promote the interaction of various institutions of higher education. The professional bodies were not mandated to substitute representative councils, but were allowed to voice an opinion in professional matters, and the option was open for the professional bodies to be granted decision making power in relevant matters.

The law contained provisions regarding the legal relations between host institution and student (at all levels), including regulations related to disciplinary liability; and it was an important new guarantee in the law that a rule allowed students to petition for the review of decisions handed down by institutions in disciplinary matters. 
All things considered, the reform process that started in 1985 was a significant breakthrough: it lead to substantive change, as well as structural change, and in this sense these measures enjoyed longevity for some time to come. Undoubtedly, the 1985 reforms had the intention of decentralization. Twenty years ago this was an important achievement, if for no other reason, because it lead to a breakthrough in what had been an over-centralized education system. Nevertheless, it did not resolve certain fundamental issues. For example, there was no rule on how an institution of higher education can be chartered, so thisin practice-could only be done by maneuvering around the legal regulations, admission of new students (enrollment) was left open for central interference, therefore the inevitable subsequent growth of the student population was not backed by provisions for the necessary prerequisites of the enlargement.

\section{Political Changes and Continuity}

The 1990 change of political systems made the revision of all legal regulation providing the foundation for the operation of the education system necessary. It was in 1993 that the first post-change law was enacted, which dealt with higher education separately. This was a reasonable development not only based on the premier role higher education had been playing in the general development of the country, but also due to the growing signs within higher education of a need for increased autonomy coupled with louder voices against state intervention. Additionally, there was great need shown for the freeing of the system from the measures limiting the size of the student population, which had long been a practice of the central administration. Even though parts of the reform concept-which also took into account international trends-were ready as early as 1988, and by 1991 a detailed concept ${ }^{1}$ had been developed, but the debate over the concept (which was held in the widest possible sphere, and included all members of the teaching staff at institutions of higher education) slowed the process of drafting a bill a lot.

There was significant resistance to the change, which restructured the system so that all institutions of higher education would belong under a single central managing organization (the government ministry in charge of education). This did affect the institutions financially, and as it would later turn out, they were affected negatively. The student population also became an active participant in the

${ }^{1}$ Concept for Higher Education Development in Hungary. Budapest, 1991. Szamel, K. (ed.): A felsöoktatás és az állam [Higher Education and the Government]. Budapest, 1990. 
preliminary debate of the bill, and their representatives lobbied hard to get the right to participate in the making of executive decisions in higher education. It turned out to be difficult to create a concept of a new financing protocol; specifically, the issue was: how to accurately calculate the true cost of higher education. Another objective was to find a way to cause the government to start treating higher education as a true priority (as opposed to the prior neglect), and at the same time result in higher education not being so dependent of central will.

The preparatory work of this bill coincided with the constitutional and administrative reconfiguration of the Hungarian state, which was not a smooth process, nor was it particularly well planned in advance at the conceptual level. The time around the political changes was charged with an energy driving public administration in general towards a more decentralized model, which-at least at the beginning-affected legal regulation as well. This was primarily true at the level of local governments, but was also signaled by the fact that tasks previously accomplished by central administration were gradually transferred to other, autonomous organizations-NGO's such as public bodies, chambers of commerce, professional organizations, public foundations, etc. (A later reaction to what would prove to be an undesirable overachievement in decentralization was administrative recentralization, i.e. the reduction of the level of self-governance.)

Autonomy became a sort of mantra all across Hungarian public administration, including the education sector, which was a natural reaction to the previously centralized system. In other words, this means the ridding of the education system of state influence, at least in theory, i.e. allowing the schools to be independent of central public administrative decision making in substantive and organizational matters alike, and it also means the strengthening of the internal leadership, as well as the role of teachers, academics in the internal governance of the institutions.

So the 1993 regulation was focused on autonomy. The autonomy model adopted by the law was the "traditional" one based on the principal of freedom of research, to which the freedom of teaching was attached, (this is the socalled Humboldt university model). This model of higher education is based on the understanding that the autonomy (self-governance and independent management) of institutions of higher education as a rule is based on the constitutional provisions guaranteeing the freedom of learning, teaching, and scientific research, in addition to the constitutional principal of unity of teaching and research. This is so because these freedoms granted by the constitution have the best chance to be applied in practice within the framework of a system, where decision-making powers largely rest with those entitled with the specific 
constitutional rights. A contrary system that has an opposite nature (such as public administrative-type management) can easily become desensitized and inpatient when it comes to violations a freedoms, and easily turns to unreasonable restrictive measures when attempting to achieve its goals, (not unlike several cases from the historical past, including especially the decades of the state socialist regime).

Institutions of higher education pressed hard for a right to participate in high-level science training as well as the power to issue science degrees (e.g. $\mathrm{PhD}$, habilitation), a right that they-at the time probably somewhat overreachingtried to secure for themselves as an exclusive title granting them sole power over these matters. In essence the institutions laid a claim on the reinstatement of rights they enjoyed prior to the state-socialist regime, rights which starting in the 1950's (based in fact on the Soviet model) were given exclusively to the Hungarian Academy of Sciences, although not barring the participation of university professors either.

The law provided the necessary framework for the practical application of yet another constitutional principle, when it prescribed for the state (as one of its duties) that it make higher education available to all citizens according to their abilities. In addition, it made the state responsible for providing financial support for this endeavor, and it made the government's duty to constantly develop education and guarantee the appropriate conditions for its operation. It was a particularly important mandate that the quota of admitted students be raised in relation to the entire young adult population, because the approximately $10 \%$ participation ratio characteristic of the Hungarian system of that time was considered to be low not only compared to Western and Northern European averages, but in the country's own regional comparison as well. The proposed increase in the number of people admitted into the system of higher education was not just a whimsical notion, rather it was based on the rather sure bet that the infusion of more highly qualified professionals into the workplaces would bring about the growth of the economy, more precisely growth is a hardly manageable target without more experts with up-to-date knowledge. The education system also had to be tuned to the developments of European norms-a moving target itself. In order to make that work, the Hungarian higher education system had to be restructured with the addition of new, more specialized fields of study and corresponding narrow curricula, taking over from the domination of fewer choices of majors that had been providing a more general blend of knowledge.

The law maintained the two basic types of intuitions of higher education. i.e. the university and the college, which basically differ in the nature of the programs and their relative length. (Universities provide a primarily scientifically- 
oriented education that normally runs five or six years, while colleges orient their programs towards practical training and issue degrees after three or four years of full time study.) Even at that time the proposal to get rid of the college category was on the table, but the 'college lobby' found support in foreign countries and managed to influence decision making inside the Hungarian Government.

An institution of higher education could either be a state school, or school sanctioned by the state (a non-state school is generally run by a foundation or by a faith-based organization). Nevertheless, the difference in ownership status did not automatically attach the duty for non-state schools to finance their operation, as all institutions presented a need for the state to finance their activities. (In connection with the constitution's guarantees of religious freedom and freedom of personal conviction, the law gave separate rules for those nonstate universities and colleges that provide theological training. Faith-based educational institutions, however, started other types of programs as well, based on the somewhat weak argument, that they are in fact performing the duty of the state by doing so, because education is in high demand, and state schools do not admit sufficient numbers of students.)

It was also at this time that in response to the demands made by the institutions of higher education all of them were listed by name in an appendix of the law. The institutions hoped that this high level of state sanction would automatically be a guarantee of financing for them. However, since there was no set rule on the procedure of founding new institutions of higher educationtrue in the case of even the state schools -, an unusual trend developed. The state would add to the appendix (listing institutions of higher education) those institutions that already had come into existence and were already functioning, (and each time this required the legislative act of amending the law). It was therefore no surprise that a virtual rush started to charter new schools as a result of the new law, and it should have been no less surprising that the central budget of the state could not keep pace with the exponentially ballooning financial burden the fast paced quantitative development brought.

The law made it the competence of the Government to set the rules for degree-requirements, and the right to approve the starting of new programs and the cancellation of existing ones in so-called 'basic training' (undergraduate core curriculum). The rationale behind this decision was that this was supposed to guarantee a desired level of uniformity of the requirements among various institutions of higher education offering the same kind of degree program. Additionally, this was to be a proof and state guarantee of the value of diplomas for citizens, and was to contribute towards the future goal of international recognition of the diplomas issued by Hungarian schools (equivalence). In 
practice, this measure, which was meant to offer guarantees, lead to a flood of new regulation, which it turn ended up making the entire system too rigid. This would prove to be a hindrance in the effort to update the substance of the education programs. Furthermore, the attempt at making degree requirements uniform across schools offering similar programs slowed the work, as it was difficult to find a consensus, and harmonize the various needs of different institutions in a single government decree. The launching of new departments was also a complicated matter, yet the logic of the system was such that it encouraged institutions to establish increasing numbers of new departments, because doing so could be used as yet another way of making the case for getting access to state financial resources. (Logical sequence: new program need, authorization of new department, new additional enrollment capacity added, additional normative financing from state budget issued based on the number of students admitted.)

The 1993 law called into life the common bodies of central administrative organizations on the one hand and the autonomous institutions of higher education on the other, and an intermediate body called the Higher Education (Scientific) Council, as well as the (Hungarian) Accreditation Committee.

The Higher Education (Scientific) Council had-and still has-a very important right to define priorities of development programs affecting the whole of the higher education system, and has influence over scientific research activity done in the framework of higher education, and over the higher education institution system's organizational structure, as well as student population quotas, and last but not least advises the state on the budget of higher education. The Higher Education (Scientific) Council is well balanced between universities and colleges, and this body also includes all government ministers involved in education, outside professional experts, representatives of cultural institutions, economic players, and society at large; parties that were supposed to represent the needs of higher education, and those financing and taking on the output of the system.

In this period of higher education reaching a mass scale it was particularly important that quality be upheld with regard to all aspects of the various tasks of institutions of higher education, so that the value of the service provided by a particular school be measured by the comparison of the set requirements obliging the school to perform well and the actual results related to their performance. The premier guarantee of the high quality of higher education is (coded into) the system itself, therefore procedures had to be devised, a system had to be created that made it possible (and in fact mandatory) for particular institutions of higher education and the community of institutions of higher education to routinely use the tool of self-evaluation; and additionally, procedures that would allow the latter to make a contribution to the preparatory process of 
governmental decision making. Based in part on foreign models, the law called into life the Accreditation Committee, which is made up of domestic and international experts, local and foreign members of the Hungarian Academy of Sciences, and additional expert bodies' representatives. They jointly evaluate the system's functioning and also set the key values that translate into priorities for its development. Once the Accreditation Committee was established, a comprehensive evaluation process, a sort of general fact finding audit of all institutions of higher education followed, which resulted in the issuing of accreditation certificates representing proof of quality (institutional accreditation).

It was probably due to the attitude inherited from the previous political system characterized by decades of dictatorial rule that the properly devised accreditation system was in practice quickly corrupted into a lobbyist club, a sort of mechanism serving interests of those better-connected institutions in the battle over support. Actual quality was replaced by just the proof of quality, and those institutions with lesser political capital and weak networking activity were left behind in the competition for financial resources allocated to development.

In practice, neither the accreditation procedure, nor the operation of the Higher Education Council had fully developed operational rules providing proper guarantees, therefore only the government minister's right (tied to the obligation of an explanation) to change the decisions made remained as a possible recourse or protection for those institutions that were negatively affected by a given decision. However, since even this ministerial overrule procedure was not fortified with unambiguous legal regulation, this institution only increased the level of unpredictability of the decision making process, instead of providing true guarantees.

The law was meant to have another type of guarantee for the protection of institutional autonomy. The Constitutional Court was given jurisdiction over matters where the state was suspected to have infringed the rights of institutions, yet in practice this institution proved to be just a threat of sanction with some chilling-effect on would-be violators of autonomy, because although most decisions handed down by the Constitutional Court would rule in favor of the party seeking an injunction, nevertheless it had no real power to remedy the unconstitutional situation.

The law also gave specific rules on the internal structure of the institutions, including the legal framework of the management configuration. The university had a single person in charge, the 'president'-so in this case the system remained unchanged-, and the college was led by a 'head director'. Even though financial matters were assigned to a financial officer, nevertheless the head director remained the person liable for financial matters as well. While 
this made the finance department subject to interference, it did not on the other hand mean that the president could in fact be held liable in case of financial misconduct.

In the defense of autonomy, a much more robust protection would have been to have subjected those decisions made in a state administrative capacity to the rules of state administrative procedure. However, the law left this question open, therefore these decisions not clearly defined as being issued by an authority could not be voided in a state administrative legal action. (Even the 2005 law only managed to remedy this problem in part.)

The various representative bodies-primarily the (university, college) Councils-got a significant role in the management of institutions of higher education. Students' representatives also had a presence in the Councils, and their participation was not merely symbolic, as they held one third of the seats. Even at the time of this rule going into force it was understood, that the presence of student representation was desirable only in those cases when the presented issue was related to students' rights. However, pressure from society was strong enough (in favor of giving more rights to students at the time) to make the stance that would have curtailed these rights politically unacceptable; because that was the norm at this early stage of the process of building a democracy, when all actual (or predicted) faults could still be attributed to a 'general lack of democracy' in the system.

It was another important feature strengthening independence that the institutions were allowed to write their own rulebooks. The government minister in charge was given the authority to act as watchdog over these rulebooks, making sure they were in accordance with all legal regulation, and it was also the minister who had the power to annul any rule that was in conflict with the law. This power was not, however, tied to any time limit; therefore the minister could expunge any institutional rule at any time. In case of the rulebooks, the rationale behind not including a statute of limitations was that it was expected that after the law was enacted all institutions would write their own rulebook more or less simultaneously, making the only viable oversight body-the government ministry-scramble in an effort to try meeting a deadline in its effort to fulfill its controlling duty. It was not particularly the case of the rulebooks that made the lack of a deadline problematic, rather it was in the case of other decisions that this posed a question of harmony with rule-of-law-state requirements, because this led to uncertainty. (For a short period between 1998 and 2000, an amendment of the Higher Education Act did contain a statute of limitations connected to this area, but this too was later taken out of the text. The decision making process surrounding this issue also had a background in politics. However, since the background story of this process is tied to particular individuals 
rather than theoretical considerations, a description of this matter would be immaterial to the present discussion.)

It was due to the 1993 law that the institution of the tuition fee was introduced into the system of higher education-even though this was only a shortlived measure. It is somewhat difficult to understand why the administration unexpectedly cancelled the merely symbolic amount charged as tuition just at a time when following the initial upheaval, the population finally accepted the new measure. Instead, a significantly more unfair institution was introduced, the so-called 'expense-compensation' system, which affected only those applicants who did not get one of the limited number of state financed enrollment places, ${ }^{2}$ but were willing and able to pay a fee in the compensation-based system. (This fee is approximately fifty times the amount of what the original tuition fee used to be, and even at the time of its introduction it was twenty times higher than the universal contribution all students had to pay previously.) In practice, the expense-compensation money is just a supplemental income for institutions of higher education. As a legal institution, its validity is highly debatable, as it is not at all obvious that it is not discriminative, that it does not violate the standard of equality, although the truth is that it works.)

The law-by granting the right of association-created a conducive environment for the fruitful interaction between institutions of higher education and their social environment (especially other scientific institutions, various institutions of the Hungarian Academy of Sciences in particular), and in theory opened the way for institutions of higher education to join one another. (In this context, the word join refers to a completely open legal institution, and from the perspective of legal dogmatics it could probably use a degree of clarification, but since it is also included in the 'local government law', it is clearly understood to be one type of a public law contract, and is definitely not a type of civil law enterprise. Today it is known in the law as the 'cooperation agreement'.) Voluntary cooperation started among institutions based on the law, but without fusion. This would probably have continued, had it not been for the so-called 'integration' started in the meantime by yet another new initiative of the state, leading to several fusions of institutions.

2 Institutions of higher education administer an entrance examination and those applicants scoring high enough to rank them in the top percentile-a number determined by various factors each year-get admission with an automatic full tuition scholarship attaché. 


\section{Yet Another Attempt at Reform, which Forces Development, by Decree, Instead of Supporting It}

Between 1993 and 1996 there were several attempts at writing a White Book of Hungarian higher education. Several groups laid their proposals on the table, but they could not in the end come to an agreement. The 1995 Parliament Resolution on the priorities of the development of higher education (107/1995) was a significant step forward in the right direction, which did in fact serve as an action plan for a few years to follow. During this short successive period Hungarian higher education had some well-defined general objectives that unified the development process across the sector.

A comprehensive set of modifications was applied to the Higher Education Act in 1997, which caused some irreversible changes to occur. ${ }^{3}$ It was during this period that the so-called integration of Hungarian higher education passed the point of no return, i.e. the fusion of various independent institutions (comprised of several departments that were located physically close to one another) into a single organizational unit. In 1996 the government ministry in charge of higher education was assigned to the liberal party, and it attempted to conduct this process with the financial support of the World Bank and intended to closely tie it to the general development of higher education, but unfortunately the reform had to be done in the absence of this outside capital infusion. Integration-although without being based on the necessary infrastructural investment-did go through in the end. During the summer of 1999 Parliament reconfigured the Hungarian higher education institutional system, which caused the overall number of existing institutions to be halved as of January 2000. (In May of 2003 there were 18 state-run universities, 12 staterun colleges; non-state run institutions of higher education were represented by 5 universities run by faith-based organizations, and 21 colleges run by faith-based organizations; and additionally, there was 1 public foundation-run university, and 9 foundation-run colleges.)

The introduction of a requirement making the preparation of so-called 'institutional development plans' mandatory for individual institutions was an important development, as it forced higher education in general to do complex and detailed strategic planning. Mandatory strategic planning made it possible for the newly integrated institutions to list their development objectives comprehensively, to

3 These changes are compiled in a textbook prepared for a particular public administration specialty exam Szamel, K. (ed.): A felsöoktatás igazgatása és tudományirányítás a felsöoktatásban [Management of Higher Education and Science Management in Higher Education]. Budapest, 1998. 
define the strategy they propose to fulfill their goals, in essence laying the groundwork for the process of securing the necessary financial resources. A negative side effect was that not all decisions were made independently, i.e. in line with organic development; therefore its truly positive advantages could hardly be sensed. Furthermore, it caused a psychological backlash rather than a positive attitude to emerge, nevertheless from the perspective of the state it brought the advantage of having to keep track of and contact with fewer institutions.

Another lasting legacy of the 1997 amendment of the law was the introduction of the credit-system, and not just any system, but one conforming to the principals of the European Credit Transfer System (ECTS)-a measure that undoubtedly had distinct advantages from the perspective of future development.

This was also the period when the transitioning to the so-called normative financing protocol occurred, which was based on a combination of the specific number of enrolled students and the cost of providing higher education in the given specialty field. The openly declared rationale behind this move was that this system intended to secure the appropriate level of financing for the institutions from the central budget, based on separately defined numbers for each specialty field. This was done despite the fact that this system was already known to be outdated even at the time of its inception. The system was so poorly designed, that it caused the amount of per capita financing within the student population (corrected for inflation) to be halved by the end of the following ten-year period.

The student loan system was also introduced after 1998, as the size of the student population enrolled in higher education was steadily increasing. One of the most important characteristics of the Hungarian higher education system in the period before 2002 was the exponential increase in the number of people wanting to participate. (There was a marked increase between 1998 and 2002, as overall enrollment numbers rose by more than $30 \%$. The total number of students enrolled in higher education almost quadrupled between 1990 and 2002, although it has to be added that almost half of the currently enrolled students participate in the expense-compensation system, i.e. they tmesleves are responsible for the cost of their education, and the state does not cover them.)

Between 1990 and 2002 the total size of the academic staff grew from 16,319 to 23,151 , i.e. the increase was only $42 \%$. When this figure is related to the size of the student population, it shows that the instructor/student ratio grew from 6.2 to $16.5-\mathrm{a}$ number that is similar to the ratio found in the European Union.

The dual nature of Hungarian higher education remained unchanged, i.e. college and university education continued to coexist in parallel universes, because they did not line up in a sequential system (as undergraduate colleges, 
and graduate programs at universities do in some foreign systems), and their share of the student population remained stable at an approximate even split.

There were several additional components of the reform that could be mentioned, which had only a short-lived positive effect immediately following their inception. These were either not very chiseled legal solutions even in the original form they were passed in, or they became dysfunctional after some time, and thus they contributed to lessening the overall affect of the original intentions. The system's response to these anomalies was a never-ending stream of additional measures, which in part led to positive reform steps, but in part had only a temporary-patch nature.

The state administered, top-heavy reforms that occurred in Hungary, and the increased autonomy, but lack of strict state supervision led to the undesirable survival of trends that should long have disappeared had a bona fide market economic model been successfully implemented in higher education.

- Instead of making their programs more up-to-date and their operations financially more viable, the institutions concentrated on increasing enrollment numbers, because they understood the somewhat inflated student body to be the key of their economic survival. This was logical thinking on their part, since the system of financing encouraged them to do so.

- The "hunger" in society for diplomas masked the alarming trend that 'diploma factories' could continue to operate with sate financial backing, despite the fact that they did not follow the logic of the market, instead were based on a statist model of a pseudo-market; a market deformed by the state.

- These circumstances caused the state to end up having to do the work of patching up the system's faults; therefore dependence on the state remained a fact of life in higher education, while referring to autonomy could defeat reform proposals.

- It is no overstatement that the functioning model evolved into a routine of micro-management, where the system was governed via direct contact between the Ministry and the institutions, the integrity of which the Ministry tried to maintain by trying to remedy problems that were the results of errors at the core of the system itself.

\section{Has Hungary Really Joined the European Higher Education Area?}

All successive administrations were aware that development of higher education would require additional financing, but none were able to make this go through during annual bargaining over the numbers of the central budget. The 
overstretched central budget could not allocate resources to the continuous development of the infrastructure of higher education, since it was already carrying the increased burden of financing the operational spending of the bloated system, filled with a growing number of students. Solutions had to be found that would release the system of higher education from the pressure of being a plaything of the annual fight over the budget, and thus manage to relatively stabilize the position of the institutions of higher education. Undoubtedly, this was one of the motivations behind the new wave of reforms that started in 2002. So the reality was that solely the Bologna Declaration or the Bologna Process did not initiate this reform, but the system itself needed comprehensive change regardless.

When the Ministry of Education launched the Accession to the European Higher Education Area project (CSEFT) in September of 2002, the Minister's intention was to comprehensively audit the system in order to identify its deficiencies and create an action plan based on this investigation, which lists the new targets. The review process involved dozens of renowned experts, each with decades of experience in conducting research into the workings of higher education systems. The several thousand pages of findings included the review of all problems of higher education, and the group made the case for starting a comprehensive and truly radical reform process. In the end, after running its course for about two years, its scope went beyond a certain level and became more particular in nature than what could be regulated at the level of law. The program grew to be a set of programs affecting higher education as a whole. ${ }^{4}$

Several inventive solutions were found in the studies submitted as part of the process of formulating the final concept, but the time was not deemed right by the Ministry of Education for these to be put into practice. Consequently, these tasks were left for the new education cabinet to be formed after the 2006

4 Magyar Felsöoktatás [Hungarian Higher Education], 2002. 7., 8., 9. contain a series of submissions on the topic of the Bologna Process. Available online at http://www.ph.hu/ph/mf/index.html

Barakonyi K.: Sorbonne-tól Prágáig: A „Bolonyai folyamat” I. [From the Sorbonne to Prague: the Bologna Process I.], Magyar Felsőoktatás, 2002. 7. 19-21; Dinya L.: A „Bolonyai folyamat” a duális képzési rendszer szemszögéből I. [The Bologna Process from the Perspective of the two-cycle education system I.], Magyar Felsöoktatás, 2002. 7. 24-25; Dinya L.: A „Bolonyai folyamat” a duális képzési rendszer szemszögéből II. [The Bologna Process from the Perspective of the two-cycle education system II]., Magyar Felsőoktatás, 2002. 8. 22-25. CSEFT: http://www.univpress.hu/data/cseft.pdf; The Bologna Process: http://www.aic.lv/ace/bologna/Prg_berl/join_mas.pdf; Components of the Hungarian Universitas Program: http://www.aic.lv/ace/bologna/Prg_berl/join_mas.pdf 
parliamentary elections to tackle. The new Minister did not reject all these proposals, and therefore some of these leftover ideas were implemented.

The formulation of the concept started in 2002 with a critically-minded and unabashed evaluation of the contemporaneous situation, and at the same time the question had to be answered: to what degree does the Hungarian system harmonize with European trends? ${ }^{5}$ During the work such an arsenal of solutions was laid on the table for various problems that their abundance was surprising even for those involved in formulating the concept. The preliminary work was being distilled into a uniform concept during what was a somewhat difficult process, as many equally important components were vying for a final place in the text of the draft law. On the one hand, experience showed that reforms changing too many elements of the system at the same time ended up failing, on the other hand some other changes would inevitably require several additional changes to be made in sequence. Changes are best carried out not simultaneously, rather following a predetermined timeline, i.e. according to a pacing that is relatively slow, but one that can potentially prevent the trend of faulty measures making their way into and remaining in the system from continuing, as had often been the case with previous reform attempts.

Making this a priority, the draft went through several revisions and compacting, and-as expected-several elements lost some degree of their "radicalism".

The forecasted cuts of the education budget to be the expected trend in coming years certainly do not infuse the higher education sector with a large degree of optimism, because even the most narrow program that can be seen as being of reform-quality would require spending that is not at all secured in the current economic environment in Hungary. Consequently, event though the reform would likely produce savings in the long run (as it did in several other countries), directors running the various institutions of higher education in Hungary only sense at this time that the state is gradually withdrawing from financing higher education instead of increasing investment, and in this sense abandons the institutions.

${ }^{5}$ Hrubos, I.: A felsőoktatás intézményrendszerének átalakulása a fejlett országokban [Development of Higher education Systems in Developed Countries]. Európa Fórum, 1998. 1. 21-34; Structural Problems of Higher Education Systems in the Age of Mass Education. In: Temesi J. (ed.): 50 éves a Budapesti Közgazdaságtudományi Egyetem. Jubileumi ülésszak [50 Years of the Budapest University of Economic Sciences, Jubilee Session]. Budapest, 1998. 1522-1530; Hrubos, I.: Transformation of the Hungarian Higher Education System in the 1990's. Civic Education Project. Discussion Series 1999. 2. 13. 
The actual goal of formulating a 'development concept' is-even if it is to serve as the foundation for the future bill to be passed by legislators-is not to produce a polished text with legal instruments formulated with exacting detail. Instead, the goal is to produce material that can then be converted into a legal form of the reform. Even though the program that was formulated did in fact take into account the legal framework, and its makers were aware of the limitations the system itself would pose from the perspective of implementation, nevertheless they focused their attention not on identifying these potential sources of conflict, instead these experts worked hardest on substantive matters, which were related to actual developmental questions from the perspective of education.

The bill (new Higher Education Act) based on the concept was eventually passed in 2005, which caused paradigm shifts to occur in the following areas, discussed below:

1. Most important is the transitioning to the multi-level system (cycles). The greatest challenge with this was that traditionally in Hungary, the dual-system was not organized according to vertically integrated tiers, rather the two systems (the college, and the university) were issuing parallel diplomas at the same level of certification. This was the base system that had to be reformed so that even the three-year (college) programs could qualify as acceptable prerequisites (foundations) for graduate-level programs issuing master's degrees. There were also the added objectives (due to financial considerations) that theoretically all students ought to be able to potentially go onto studying at a master's level, but in practice only the more talented students should actually get into a master's program, which was financed at a higher per capita rate. It is difficult to define specific numbers in relation to this objective, but the law, nevertheless, managed to fix the number of students going onto the second tier of training at approximately one third of the number of students graduating at the lower prerequisite level. This was at least the criterion for centrally financed enrollment places.

Even though there was intense objections to accepting the changes in the beginning, it seems that by now most institutions have accepted the Bologna education method, and have either registered to participate in the system, or have a registration process of their so-called Bologna Departments underway.

In addition to the two basic tiers (or with the post-graduate training the three training cycles) there are several supplementary forms of training providing further specialized knowledge or additional expertise in a shorter period time.

According to the law, even colleges are certified to conduct training and to issue diplomas at all levels, but in the long run it is predicated that the dual- 
system (of parallel institutions) will cease to exist (because it will lose all rationality), or alternatively the nature of colleges will change: (instead of being specialized-science-oriented institutions they will likely become training centers offering a more practical-training-oriented education.)

The set of reform measures necessitates the updating of the credit system. At the present time, the Hungarian education system does not fully take advantage of the true value, or the full potential of the credit system. This is yet another proof that if a certain new measure-even if it is a very rational and progressive one at its core-is introduced into the system without the affected people who work in the system truly sensing the necessity of it, then the state mandated changes only produce hollow results that are more for show than bona-fide change, therefore the desired results leading to increased rationality are usually lacking in the end. One could identify important socio-psychological characteristics here, if this were a relevant subject matter in the present discussion, but it is more important in this context to state the fact that in the end it was not a fruitless and completely irrational measure on the part of the state to force the introduction of the credit system, because its 1997 launching has by now led to positive results. Already, it has demonstrable advantages from the perspective of the students: in the event a student does not meet the prescribed requirements in a particular academic year, it does not automatically result in having to repeat the entire academic year, rather the system is able to accommodate individual differences by taking into account personal disadvantages as well as evaluating progress on a student by student basis. In order for this to work properly the system must be developed further, but at least the foundation of a properly operating system is now in place.

2. Reform concepts formulated in advance of the 2005 Law were guided by intentions to fundamentally change the system of financing in such a way that it would secure the long-term continuous functioning of higher education, and somehow cover gaps in financing where the state does not provide the necessary funds. The original reform concept was that admitted students would receive their share of state financial aid via a "virtual student-voucher", which also functions as a sort of state financed loan, and is to be paid back to the central state budget over the course of a graduate's professional career. This would have secured the necessary additional financial resource that the system had always been lacking. The long term repayment scheme-as things stand today-has been neglected in favor of introducing a short term institutional financing scheme, which is essentially based on the premise that students are to contribute to the cost of their education, which can be financed optionally by taking out student loans. Nevertheless, free higher education is tied to 
performance (a set GPA), and even in its current form covers only ten percent of the student population.

There were other inventive solutions proposed as well, starting with the premise that the state's inability to finance the system would be overcome by a sort of delayed privatization, but this solution was deemed unacceptable in the end not only by representatives of higher education but by politicians as well. This proposed solution had only a very slight representation in the final text of the law as it was passed, and this was in the form of the right to acquire real property being expanded to include state financed institutions of higher education as well, although with the limitation that their purchases can only be financed with revenue derived from their own entrepreneurial activity. (Some believe even this limited right to be an extremity, as they hold that privatization should have no place in higher education even at a conceptual level.) The 2005 law, however, allows the transfer of the right of a maintainer to finance a particular institution.

The idea has been repeatedly proposed that the legislature ought to pass a separate higher education financing law, since an increasing portion of the current Higher Education Act is taken up by the regulations related to financing, which are all executed via government decrees, whereby the rules, in practice, change with annual regularity, to make it possible to break down the annual budget according to current needs. This creates an uncertain situation for the institution, which encourages them to spend without prudence, because they cannot rely on a long-term predictable cash flow guaranteeing that development projects they start would have finishing funds provided by necessary budget appropriations. Perhaps the time is still not yet ripe for this new system of financing to be implemented, but there are attempts at formulating a new 'credit-financing' system based on funds allocated according to credit units. ${ }^{6}$

The poor balance sheets of the institutions made it unavoidable that rules be formulated providing additional economic freedom for intuitions of higher education, allowing more financial leeway for them than what was the norm for other budgetary organizations. As of 2003, the State Finance Act includes a rule that allows individual institutions of higher education to internally reallocate financial resources they are apportioned in the central budget; furthermore, they are allowed to keep and accumulate moneys not spent in a given year, to maintain a separate account for revenues they themselves generate,

${ }^{6}$ Temesi J. (ed.): Finanszírozás és gazdálkodás a felsőoktatásban [Financing and Financial Management in Higher Education]. Budapest, 2004. 443; Polonyi, I.: Oktatásgazdaságtan és oktatáspolitika [Education Economics and Education Policy]. http://www2.zskf.hu/media/oktpolea05.ppt 
to conduct entrepreneurial activity free of taxation, to sell real estate for the financing of development projects, to set up a venture fund, and to take out loans. The law regulates the setting up of a provision of cover fund, which is a legal form created for the combined participation of multiple institutions of higher education wanting to conduct infrastructural development projects. (Since this was already regulated in 2003, the new Higher Education Act of 2005 incorporated rules that already existed.)

3. Another important issue that needed resolution was the organizational reform of the state management and oversight structure and its ways and means. The concept the law was based on included radical reform proposals in this area as well, which not only affected the competency of Parliament, the Government, and the Minister, but also proposed that the legal framework of intermediate bodies be more exactingly and narrowly defined. Above all, it attempted to more unambiguously define the scope of competency of each such body, giving special attention to ridding the system of redundant parallelisms, ending the trend of the decisions of the Hungarian Accreditation Committee (MAB) having administrative authority function, and the restricting of the advisory function of the Higher Education Council to just economic issues.

Since administrative authority functions were not native to the original tasks of the accreditation committee (as an accreditation committee is charged with certifying quality and not with authorizing operation), it was logical that these functions would have to be charged to another organization, even if this had the unpleasant consequence of having to set up an additional new body, in order to avoid the situation, where the organization that would hand down decisions related to operational matters would be of a kind, which was producing decisions that could not be overruled. Therefore, some of the administrative functions of the education sector were assigned to the competence of the new registration center. These matters fell under the rules of state administrative procedure, and had a judgment of first instance power.

A new characteristic of the law is that procedures related to the operational matters of institutions of higher education-from the chartering of a new institution to giving tenure to a university professor-are regulated in detail, including exact definition of the tasks and competence-limits of those participating in the process, as well as the similarly detailed regulation of legal redress. Some of the administrative functions of the education sector were assigned to the competence of the new registration center. These matters fell under the rules of state administrative procedure, and had a judgment of first instance power.

The following were entirely new organizational tasks: quality management, higher education information system, operation of the career-tracking system; 
and the institution of the Office of the Commissioner for Educational Rights, and the Mediation Service for Education (OKSZ). The legal oversight of the operation of the maintainers of the institutions is allocated to sector management (Government Ministry), while the legal oversight of the institutions themselves is a right of its maintainer.

There were conceptual conflicts surrounding the management function of the maintainers and other management rights residing with state management agencies. The new law had to resolve these conflicts by sharply demarcating the various competences and clearly assigning rights to just one sphere or the other without overlapping. The maintenance and management tasks of institutions of higher education include the chartering, the closing, and the reorganization of institutions; the right to regulate budgetary issues, to set operational rules, the right to perform the duties of an employer, the right to make appointments, as well as the guaranteeing of lawful operation, and institutional autonomy. These tasks of the maintainers are uniformly described in reference to all institutions, whether they are state-run or not.

4. The concept that was the foundation of the 2005 Law prescribed a management model that-reflecting some other European examples-would essentially separate the academic and economic management of the institutions into two independent units that cooperate with each other. In this scenario, the Institutional Council in charge of economic management would have been the body accountable for prudent institutional financial management and in charge of strategic targets-all the while cooperating with academic management. In this system, the president's supreme power within the institution would have been curtailed, as he/she would have become the mere executor of the decisions of the Institutional Council, a radical shift in competences.

Not surprisingly, this was the one measure that ran into the strongest opposition from the institutions and even led to an uproar, so much so that in the end they managed to block this structural change. While this proposal of the Education Cabinet did reach the legislature, and in fact the bill was passed by Parliament with the new structure included, nevertheless the Constitutional Court ${ }^{7}$ struck this passage from the law based on an argument that institutional autonomy needed to be protected. The case was brought by the President of Hungary based on an argument founded on the fact, which was later upheld by the court in its decision, that Section 70/A of the Hungarian Constitution prescribes the freedom of sciences. The decision also included references to previous practices of the Court, and to the opinion that this freedom cannot be

${ }^{7}$ Constitutional Court Decision No. 41/2005. (X. 27.). 
exercised without the right to have a say in the operational matters of the institution.

The consequence of the Constitutional Court Decision was that the law had to be amended in order to fill the gap left by the struck passages. Since the governing bodies proposed by the concept, which would have been the executive bodies that would have exercised the right of economic management (derived from the rights assigned to the maintainers) could not be set up, these rights are exercised on the one hand by the Senate, as the highest level executive body of an institution of higher education, and on the other hand by the maintainer. Additionally, the so-called economic council was created, which is charged with the task of preparing materials in advance of decision making, and the right to formulate an opinion on economic decisions made in the institution.

It was also based on the Constitutional Court decision that the rights of the maintainer were revised: the maintainer is charged with the oversight of the lawful operation of the institution, but has no direct ability to intervene in operational matters, rather if the maintainer's repeated requests to correct some perceived operational malfunction is not fulfilled and the problem is not remedied, then the maintainer can initiate court proceedings in order for the court to declare the violation of the law. According to the new regulation, the maintainer sets the figure allocated to the institution as its financing, but the maintainer's approval of the specific budget (line items) is no longer required.

This series of measures running their course over a five-year period eventually led to an outcome where institutions of higher education have increased financial independence and economic autonomy. This economic autonomy is the true basis for professional autonomy, because realistically no professional decision-making power can be properly exercised without the appropriate economic decision-making rights.

There were several additional issues regulated by the law, such as:

- The diplomas and other certificates issued within the education system had to have a system of comparing them.

- A new aspect of the law is that it gives specific guarantees in relation to the legal relationship between the student and the institution, including the way they enter into this relationship, maintain it, suspend it, or dissolve it.

- It is in connection with the legal relationship between student and institution that the law regulates the differentiated higher education admission system, with the declared goal that those students performing at the highest level nationally within the secondary school system (built around a uniform requirement set) get those enrollment positions in higher education that are state financed. (This is true with all cycles of the 
system: basic level, masters level, doctoral training, as well as specialization training, and accredited higher vocational training.

- The equal opportunity requirement is introduced as a new requirement adopted from European practice, including the representation of women in appropriate numbers, support of disadvantaged students, and the legal regulation mandating the creation of environments friendly to physically disadvantaged people.

- The law creates a uniform institutional practice by way of a consistent attitude toward all relevant regulation of those services that guarantee student's living and working conditions being appropriate in terms of studies, career, sporting, extracurricular activities, healthy lifestyles.

- Naturally, all this ${ }^{8}$ is done in the law in accordance with the relevant directives of the European Union.

As of 2006, the education cabinet is finally in a state where it can essentially focus on the execution of the law. The Government has also issued a set of

8 Just to name only the more important ones:

- The law prescribes the ban of negative discrimination in order to execute the directives contained in 2000/43/EC, which defines the standard of equal treatment of all persons regardless of their race or ethnicity.

- The European Communities Council Directive No. 93/96/ECC sets the rules of students residency rights, which is the basis for the law's regulation related to entering into the legal relationship between student and host institution

- The European Communities Council Directive No. 1612/68/ECC sets the rules for the free movement of workers within the Community, which is the basis for the law's regulation related to employment issues.

- The European Communities Council Directive No. 1999/70/EC based on a framework-agreement by ETUC, UNIC, UNICE and CEEP related to definite-term employment is the basis in the law for regulation related to employment status, and entering into a public employee status.

- The Council has a proposal dated September 24, 1998. on pan-European cooperation on the quality-assurance of European higher education, which is the basis for the law's regulation related to the functioning of Hungarian Accreditation Committee (MAB), and the accreditation procedure.

- The European Parliament and the Council's Directive No. 2001/19/EC on the general system for the recognition of professional qualifications amends Council Directives 89/48/EC and 92/51/EC, in addition to directives on general nurses, dentists, veterinarians, midwives, architects, pharmacists, and medical doctors 77/452/ECC, 77/453/ ECC, 78/686/ EEC, 78/687/ EEC, 78/1026/ EEC, 78/1027/ EEC, 80/154/ EEC, 80/155/ EEC, 85/384/ EEC, 85/432/ EEC, 85/433/ EEC and 93/16/ EEC.

The execution of the directives listed above is guaranteed by the law via its regulation of the structure of the education, and the regulation of the requirements of attaining various degrees and special certificates, and those of entering higher education. 
decrees necessary for the proper execution of the law. The novelty (from a legal perspective) here was that several solutions that were necessary for the execution of the new Higher Education Act were combined in a single directive.

Government Decree No. 79/2006 (IV.5) gives rules on the execution of new legal institutions created by the Higher Education Act. One of these was the setting of minimum requirements that are to be met when a new institution of higher education is chartered, as well as setting procedural rules for chartering a school. This primarily fills the role of providing a guarantee that the appropriate staff and infrastructure is available for the school to properly work even if the prescribed maximum permissible enrollment capacity is fully utilized. As far as faculty is concerned, the Decree creates an environment that allows professors not to have multiple public servant employment relations at several different institutions of higher education. The way to keep track of this is via a so-called 'instructor code', which-according to the Decree-had to be created for all faculty members by the end of December 2006, and it had to also be issued to them by this date. The reason behind this measure was that in the past decade accreditation trends caused leading professors to have several employment contracts. The multiple employment situation actually benefited no one involved: students could only establish a rather more limited personal relationship with their 'wandering-teachers'; it was a burden for the institutions as well, because they were essentially issuing paychecks to „Dead Souls” (as in the title of Nikolai Gogol's epic poem), who could not take their fair share of the load of teaching and (other faculty) work; and in fact this was cumbersome and unpleasant for the professors as well, who could not make close ties with any given institution while at the same time being overloaded with work.

The Decree also gives detailed regulation of the so-called 'higher level specialty training'. This institution, which is not very good in its naming or otherwise, took root in the Hungarian legal system in 1997 (when it was named 'accredited schooling system higher level specialty training course'), which could be conducted both by secondary schools and institutions of higher education. Students are not issued any diploma at completion time, but it provides students with specialty certification, and knowledge acquired during the course(s) are convertible to transferable credit in case the student goes on to study in another higher education program. In fact, the true practical advantage was that at the time the credit system was launched it was important to demonstrate the utility of credit transferred from outside, and also this gave an additional chance for getting a diploma for those young adults who would have previously be destined to merely getting professional specialty certification. In practice, this level of training is overwhelmingly conducted by 
secondary schools based on agreements they enter into with institutions of higher education. (In its current function, it has become a hidden form of inflating enrollment figures at colleges and universities.)

Rules on the higher education information system prescribe that the institution in charge is the Higher Education Information Center, which keeps record of data on higher education development (and financing) received from the institutions. Since in Hungary the Privacy Act (Law on the Protection of Private Information and the Freedom of Information of a Public Nature) says that legitimate data transfer can only occur based on specific mandate given by law, therefore the scope of the data to be provided by the institutions is defined in an appendix of the Higher Education Act, but the method of data transfer is described in the Government Decree. (The student and faculty identification numbers are also tracking aids created for the express purpose of making people identifiable by the data management system.)

This decree also contains the rights of students with learning difficulties or physically disadvantaged persons, and special regulations connected to modified examination methods for them, or possible waivers related to exempting them from meeting requirements otherwise prescribed by law (e.g. exemption from under the relevant part of a foreign language test for students suffering from dyslexia, or hearing or vision impairment.)

Rules on implementing the credit-based system are also found in this decree (such as the principal rules of the institutional credit system, rules of related record keeping, etc.). Additionally, the body called Credit Council and Bureau established in 1997 was carried over into the revised system, an institution identified as the premier organization charged with the continuous development of the credit system, and is also identified as the information center in international credit matters.

There were some additional new rules created that intend to improve the overall situation of students. One of the most important measures was the raising of the student loan ceiling (larger sum), as well as the widening of the scope of eligible individuals (expense-compensation based students, doctoral students, students opting to attend an institution of higher education in another European Union member state). While this is not a perfect solution, as it does not-especially in the case of those studying abroad-cover living expenses, nevertheless, it undoubtedly eases the financial burden of students' families, therefore they can participate in higher education independently of their financial background.

Based on all of the above, the transitioning process has a fair chance of succeeding. 
Today, we expect to see a trend take shape in the forthcoming years, where the implementation of the reform will lead to more instances of state participation in order to weed out overpopulated but dysfunctional programs that produce graduates that join unemployment lines in droves on the day of their graduation. It has become clear by now, that neglecting needed development projects was harmful, and this problem is not effectively offset by the otherwise positive development that grants the right for institutions to generate income of their own, a right previously barred. While the state is no longer paternalistic in its attitude toward higher education, it still maintains tight controls.

The question remains unanswered whether central budget cuts have caused the system to operate more efficiently, and rationally. It is unclear also if increased enrollment, more courses, quantitatively more expectations of students and academics alike can be understood as higher achievement on the part of the system. At the moment the answer is probably no, or at least the issue is ambiguous. The one positive aspect is that students graduating from now on will face an achievement oriented workplace environment, and they become aware of that in time, and they understand that they themselves are responsible for being prepared to face this unforgiving professional environment. They understand that they need to make sacrifices, and are willing to invest (in their own "human resource capital"), and then they will be able to succeed, although perhaps differently from how it was once imagined. In some sense this is also true for the institutions of higher education as well: they are not spoiled brats, therefore they are forced to find a way to survive. 